\title{
Neglected Risks: The Psychology of Financial Crises
}

\section{Citation}

Gennaioli, Nicola, Andrei Shleifer, and Robert Vishny. 2015. Neglected Risks: The Psychology of Financial Crises. American Economic Review 105, no. 5: 310-314. doi:10.1257/aer.p20151091.

\section{Published Version}

doi:10.1257/aer.p20151091

\section{Permanent link}

http://nrs.harvard.edu/urn-3:HUL.InstRepos:33077926

\section{Terms of Use}

This article was downloaded from Harvard University's DASH repository, and is made available under the terms and conditions applicable to Other Posted Material, as set forth at http:// nrs.harvard.edu/urn-3:HUL.InstRepos:dash.current.terms-of-use\#LAA

\section{Share Your Story}

The Harvard community has made this article openly available.

Please share how this access benefits you. Submit a story.

Accessibility 


\title{
Neglected Risks: The Psychology of Financial Crises ${ }^{\sharp}$
}

\author{
By Nicola Gennaioli, Andrei Shleifer, ANd Robert Vishny*
}

Financial crises are supposed to be rare events, yet they occur quite often. According to Reinhart and Rogoff (2009), investors suffer from "this time is different" syndrome, failing to see crises coming because they do not recognize similarities among the different pre-crisis bubbles. As a result, each crisis surprises investors.

Economists typically model financial crises as responses to shocks to which investors attach a low probability ex ante, but which nonetheless materialize. Such shocks (sometimes referred to as "MIT shocks"; e.g., Caballero and Simsek 2013) are consistent with rational expectations in that investors recognize that there is a small chance that the shock might occur, but they are harder to reconcile with the Reinhart Rogoff (2009) observation that crises are not that unusual.

The 2008 financial crisis in the United States has deepened the challenge, by bringing up direct evidence that investors underestimated the risk of a crisis. Coval, Jurek, and Stafford (2009) show that investors underestimated the probability of mortgage defaults in pricing mortgage backed securities. Foote, Gerardi, and Willen (2012) find that investors did not even contemplate the magnitude of home price declines that actually materialized. Rather than being considered unlikely, the risks appear to have been entirely neglected. We need a theory of beliefs consistent with sharp underestimates of the odds of a crisis.

In this paper, we present a psychological theory of the neglect of risk and financial crises. The

\footnotetext{
* Gennaioli: Department of Finance, Universita Bocconi, Via Roentgen 1, Milan, Italy (e-mail: nicola.gennaioli@ unibocconi.it); Shleifer: Economics Department, Harvard University, Littauer Center, 1805 Cambridge Street, Cambridge, MA 02138 (e-mail: shleifer@fas.harvard.edu); Vishny: Chicago Booth, University of Chicago, 5807 South Woodlawn Avenue, Chicago, IL 60637 (e-mail: Robert. vishny@chicagobooth.edu). Gennaioli thanks the European Research Council (Starting Grant \#241114) for financial support.

${ }^{\dagger}$ Go to http://dx.doi.org/10.1257/aer.p20151091 to visit the article page for additional materials and author disclosure statement $(\mathrm{s})$.
}

theory seeks to explain precisely why the probability estimates of a crisis in a boom are too low, offering a foundation of "unanticipated" shocks, and of zero probabilities attached to some states of the world by investors (Gennaioli, Shleifer, and Vishny 2012). Our theory yields boom-bust financial crises based entirely on beliefs; we do not incorporate into the model any economic mechanisms that amplify the shocks, such as fire sales or imperfect capital markets.

Our theory is based on Kahneman and Tversky's (1972) idea of representativeness, previously modeled by Barberis, Shleifer, and Vishny (1998); Gennaioli and Shleifer (2010); and Bordalo, Gennaioli, and Shleifer (2014). In our model, representativeness induces people to overestimate the probability of outcomes that are relatively more likely in light of recently observed data. Representativeness is intimately related to the idea of similarity: after seeing some data, people concentrate their forecasts on outcomes similar to the data observed, neglecting alternative future paths.

This principle has far-reaching implications for finance. An investor observing a string of good news (Internet stocks, housing prices) views them as being generated by a favorable economic scenario. A series of good news is similar to a continuing boom. The investor then puts too much probability weight on that scenario and neglects the risk of bad outcomes. If investor expectations are elicited at this point, they look extrapolative.

Observing some bad news intermixed with good news does not change the investor's mind. He views the bad news as an aberration and under-reacts. It takes a string of unfavorable news to render the bad outcome sufficiently more likely that the representative scenario changes from boom to bust. A pattern of sufficiently dramatic or continuing bad news is similar to the low payoff state, leading to a change in the underlying beliefs. Previously ignored bad news is remembered, leading to a sharp rise in the perceived probability of a crisis and a collapse of 
prices. The investor now overreacts to the bad news, especially if the true probability of the low state remains low. The possibility of black swans is initially ignored, but ultimately turns into an overstated fear that leads to a self-generating crisis. In contrast to rational expectations, the model yields purely belief-driven boom bust cycles.

\section{The Model}

There is one asset, such as a mortgage, and one investor. The cash flow of the asset, received at the very end, is a random variable taking values in $Y \equiv\left\{y_{h}, y_{l}\right\}$, where $y_{h}>y_{l}$. There are three periods $t=0,1,2$. The investor receives bits of news about the probability of each final payoff between periods, and updates his beliefs (the news could be payoff realizations of similar assets). At $t=0$, the investor's prior expected probability of $y_{k}$ is $\pi_{k}^{0}$, with $\pi_{h}^{0}>\pi_{l}^{0}$. We do not think of either state as extremely unlikely, although good times are more likely than bad. At time $t$, after observing a sample of $\left(n_{h}, n_{l}\right)$ bits of good and bad news, a Bayesian investor would update the posterior expected probability of $y_{k}$ to $\pi_{k}^{t}=\left(\pi_{k}^{0}+n_{k}\right) /\left(1+n_{h}+n_{l}\right)$. This updating rule obtains if the prior distribution over $\left(\pi_{h}, \pi_{l}\right)$ is Dirichlet with parameters $\left(\pi_{h}^{0}, \pi_{l}^{0}\right)$.

At $t=1$, debt is issued to the investor against the asset's cash flow. Issuers maximize profits. The investor is assumed to be risk neutral as long as the expected default probability is below $\rho$, but infinitely risk averse if the expected probability of default is higher than $\rho$, where $\rho<\pi_{l}^{0}$. This discontinuity in risk bearing capacity may reflect an institutional constraint facing the investor, such as a value-at-risk constraint.

To see what happens in a boom, assume that, between $t=0$ and $t=1$, a string of $n_{h}^{0}$ good draws is observed, and no bad news. By Bayesian updating, the expected probability of state $h$ at $t=1$ is $\pi_{h}^{1}=\frac{\pi_{h}^{0}+n_{h}^{0}}{1+n_{h}^{0}}>\pi_{h}^{0}$. To make our points, we assume

$$
\rho<\pi_{l}^{1}=1-\pi_{h}^{1} .
$$

Good news increases the expected probability of a good state, but not enough to make it tolerable for investors to bear default risk in the low state $y_{l}$. We then have:
LEMMA 1 (Rational Benchmark): Under A1, after the observation of $n_{h}^{0}$ bits of good news, the amount of debt issued at $t=1$ and its price are $d_{1}=p\left(d_{1}\right)=y_{l}$.

A moderate amount of good news does not change the Bayesian posterior enough. As a consequence, the amount of debt issued and its value do not change relative to what would in principle have happened at $t=0$ if debt were issued then. The rational expectations funding policy is very conservative. This (low) amount of debt is completely information insensitive, so its price does not change at $t=2$ either.

\section{The Boom Under Thinking through Representativeness}

In contrast to the rational benchmark, suppose that belief formation is guided by representativeness. In particular, what is representative at $t$ depends on a comparison with the past, $t-1$.

DEFINITION 1: At time $t$, the representativeness of cash flow $y_{k}$ is formally defined as

$$
R\left(y_{k}, t\right)=\frac{\pi_{k}^{t}}{\pi_{k}^{t-1}}
$$

Investors then deflate by a factor $\delta \in[0,1]$ the odds of the less representative cash flow. Equally representative cash flows are deflated by the same factor.

Representativeness maps reality into what investors are thinking about. The most representative cash flow at $t$ is the one whose probability exhibits the largest percentage increase in light of the data. 1 The probability of this cash flow is inflated relative to the less representative one (but probabilities still add up to one). Intuitively, investors weigh recent data too much in their assessments.

\footnotetext{
${ }^{1}$ Tversky and Kahneman (1983, p. 296) write that "an attribute is representative of a class if it is very diagnostic; that is, if the relative frequency of this attribute is much higher in that class than in a relevant reference class." In line with this definition, our model specifies that a cash flow realization is representative of a sequence of data if such realization becomes relatively much more frequent after the data are observed.
} 
Parameter $\delta$ captures the severity of the distortion of probabilities. When $\delta=0$, investors only think about the most representative cash flow, forgetting the other. This case corresponds to a complete neglect of risk, as in Gennaioli, Shleifer, and Vishny (2012). When $\delta=1$, investors hold rational expectations. For intermediate $\delta \mathrm{s}$, investors overestimate the likelihood of representative states.

Consider now the implications of this logic. Begin with a stable situation in which no updating occurs and the distribution $\pi_{k}^{t}$ is always the same as $\pi_{k}^{0}$. By equation (1), in this case all cash flows are equally representative, since $R\left(y_{k}, t\right)=\pi_{k}^{0} / \pi_{k}^{0}=1$. Even under representativeness, then, the rational benchmark $d_{1}^{r}=p^{r}\left(d_{1}^{r}\right)=y_{l}$ obtains.

Consider what happens in a boom under representativeness. Now, observing $n_{h}^{0}$ bits of good news exerts a more drastic effect on beliefs than under rational expectations. Under representativeness, this news does not just raise the probability of the high cash flow state, but it also renders that state representative. The following result holds:

PROPOSITION 1: Under representativeness, after observing $n_{h}^{0}$ pieces of good news the beliefs $\pi_{k}^{r, 1}$ of investors at $t=1$ are distorted in favor of higher cash flows:

$$
\begin{gathered}
\pi_{h}^{r, 1}=\frac{\left(\pi_{h}^{0}+n_{h}^{0}\right)}{\left(\pi_{h}^{0}+n_{h}^{0}\right)+\pi_{l}^{0} \delta}>\pi_{h}^{1}, \\
\pi_{l}^{r, 1}=\frac{\pi_{l}^{0} \delta}{\left(\pi_{h}^{0}+n_{h}^{0}\right)+\pi_{l}^{0} \delta}<\pi_{l}^{1},
\end{gathered}
$$

where $\pi_{k}^{1}$ is the Bayesian posterior. If $\delta$ is small enough, after observing $n_{h}^{0}$ bits of good news the debt issued at $t=1$ and its price are $d_{1}^{r}=y_{h}, p^{r}\left(d_{1}^{r}\right)=y_{h}-\pi_{l}^{r, 1}\left(y_{h}-y_{l}\right)$.

When the investor assesses risk by representativeness, he overreacts to good news. Good news increases the probability of $y_{h}$, but the investor extrapolates too much from this favorable change. As a consequence, he downplays the probability of $y_{l}$, which facilitates greater debt issuance at higher prices. If $\delta \rightarrow 0$ these effects are so strong that debt is viewed as absolutely safe, so its price equals the maximum $p^{r}\left(d_{1}^{r}\right)=y_{h}$. Compared to the rational case, debt is over-priced and over-issued, as in Gennaioli, Shleifer, and Vishny $(2012,2013)$.

Although investors fail to fully anticipate the risk of losses, they do so not because losses occur with a low probability. In fact, the loss state $y_{l}$ may be quite likely. Losses are neglected because they are not representative of the good news that market participants have observed. This is a form of "this time is different syndrome": the good news creates too much faith in good fundamentals, which leads to neglect of risk and excessive debt issuance, as in Baron and Xiong (2014). Extrapolation of good times and the neglect of downside risk are part of the same psychological mechanism of representativeness.

This mechanism highlights two major differences between this psychologically founded model and the canonical "unanticipated shock." First, markets will get exposed to the risk of losses rather frequently: even relatively likely outcomes such as $y_{l}$ may be neglected. Second, the risks that get neglected endogenously depend on actual fundamental changes and news. This is a testable implication.

\section{The Bust under Thinking through Representativeness}

Another key difference between the psychology of neglected risks and the canonical "unanticipated shock" is how crises unfold. Under representativeness, a few disappointing bits of data intermixed with good news are not enough for neglected risks to become salient. Enough bad news must accumulate for the bad scenario to become representative. As a consequence, investors initially under-react to bad news, but when enough bad news accumulates, investors over-react because their representation changes, causing them to overestimate the probability of the low state. There is an exact parallel here between the psychology of booms and busts.

To see how this works, suppose that after $t=1$ a number $n_{l}^{1}$ of low realizations is observed intermixed with $n_{h}^{1}$ high realizations, so that the news sample at $t=1$ is $\left(n_{l}^{1}, n_{h}^{1}\right)$. At $t=2$, then, the market beliefs $\pi_{k}^{r, 2}$ and outcomes are:

PROPOSITION 2 (Under- and Over-reaction): Suppose that psychological biases are severe, 
namely $\delta \rightarrow 0$. Then the market reacts to news $\left(n_{l}^{1}, n_{h}^{1}\right)$ as follows:

(i) If $n_{l}^{1} / n_{h}^{1}<\pi_{l}^{0} /\left(\pi_{h}^{0}+n_{h}^{0}\right)$, the market neglects the bad news and still believes that debt is perfectly safe, namely $\pi_{h}^{r, 2}=1$ and $p^{r}\left(d_{1}^{r}\right)=y_{h}$.

(ii) If $n_{l}^{1} / n_{h}^{1}>\pi_{l}^{0} /\left(\pi_{h}^{0}+n_{h}^{0}\right)$, the market over-reacts to the bad news. It now believes that $y_{l}$ occurs with probability 1, namely $\pi_{h}^{r, 2}=0$ and $p^{r}\left(d_{1}^{r}\right)=y_{l}$.

This result is particularly stark due to the extreme assumption $\delta \rightarrow 0$, but it brings out our main points. First, provided only a few bits of bad news are observed, investors disregard them, and continue to extrapolate from the more representative good news. Relative to rational expectations, the reaction to information is delayed. This result may shed light on one of the most puzzling aspects of the pre-Lehman market behavior in the United States, when investors shrugged off extremely bad news during 2007-2008, such as the collapse of Bear Stearns and several market runs, and only panicked after Lehman.

Second, after many bits of bad news are observed, the low state with large losses on debt becomes representative. At this point, investors discard the good news as mere instances of chance and exaggerate the likelihood of future losses. Investors become pessimistic according to the same psychology that caused euphoria at $t=1$. An event such as the collapse of Lehman reminds investors of all the other bad things that have happened, fundamentally changes beliefs, and leads to a crisis.

In Proposition 2, low probability outcomes require relatively few observations to become representative (formally $n_{l}^{1}$ can be low precisely when $\pi_{l}^{0}$ is low). Bad news episodes are dangerous because they very quickly change representation, not because of the objective (and unlikely) consequences they bring about. More generally, representativeness can cause large swings in confidence and thus in market outcomes in response to news, increasing volatility relative to rational expectations.

\section{Conclusion}

We have outlined a psychological model of beliefs in financial markets in which investors attach excessive probabilities to states of the world that are representative for the news they observe. In this model, optimism and pessimism are outcomes of the same psychological mechanisms. The very simple model yields several results.

First, it explains how moderate probability events are first neglected, but then exaggerated when news pattern becomes consistent with them. It thus accounts for "this time is different" phenomenon without recourse to low probability shocks.

Second, it provides a unified psychological interpretation of neglect of risk and extrapolation that have been seen as central to the accounts of boom and bust cycles. This framework also allows for thinking about under- and over-reaction to information that has been a central set of phenomena in behavioral finance, but has not yet been obtained in a unified psychological model (see Barberis, Shleifer, and Vishny 1998).

Third, it explains how boom and bust cycles in debt valuation and issuance can arise purely through volatility in expectations, even without the standard economic mechanisms of amplification.

Obviously we have presented only a rudimentary version of this analysis. Yet the goal of having a unified psychological model of financial instability appears a bit closer.

\section{REFERENCES}

- Barberis, Nicholas, Andrei Shleifer, and Robert Vishny. 1998. "A Model of Investor Sentiment." Journal of Financial Economics 49 (3): 307-43.

Baron, Matthew, and Wei Xiong. 2014. "Credit Expansion and Neglected Crash Risk." Unpublished.

Bordalo, Pedro, Nicola Gennaioli, and Andrei Shleifer. 2014. "Stereotypes." National Bureau of Economic Research Working Paper 20106.

- Caballero, Ricardo J., and Alp Simsek. 2013. "Fire Sales in a Model of Complexity." Journal of Finance 68 (6): 2549-87.

-Coval, Joshua, Jakub Jurek, and Erik Stafford. 2009. "Symposium: Early Stages of the Credit Crunch: The Economics of Structured Finance." Journal of Economic Perspectives 23 (1): 3-25. 
Foote, Christopher L., Kristopher S. Gerardi, and Paul S. Willen. 2012. "Why Did So Many People Make So Many Ex Post Bad Decisions? The Causes of the Foreclosure Crisis." Federal Reserve Bank of Boston Public Policy Discussion Paper 12-2.

Gennaioli, Nicola, and Andrei Shleifer. 2010. "What Comes to Mind." Quarterly Journal of Economics 125 (4): 1399-1433.

Gennaioli, Nicola, Andrei Shleifer, and Robert Vishny. 2012. "Neglected Risks, Financial Innovation, and Financial Fragility." Journal of
Financial Economics 104 (3): 452-68.

-Gennaioli, Nicola, Andrei Shleifer, and Robert Vishny. 2013. "A Model of Shadow Banking." Journal of Finance 68 (4): 1331-63.

- Tversky, Amos, and Daniel Kahneman. 1983. "Extensional Versus Intuitive Reasoning: The Conjunction Fallacy in Probablity Judgment." Psychologial Review 90 (4): 293-315.

Reinhart, Carmen M., and Kenneth S. Rogoff. 2009. This Time Is Different: Eight Centuries of Financial Folly. Princeton: Princeton University Press. 
This article has been cited by:

1. Anjan V. Thakor. 2015. The Highs and the Lows: A Theory of Credit Risk Assessment and Pricing through the Business Cycle. Journal of Financial Intermediation . [CrossRef] 